\title{
Evidence for a role for the gumB and gumC gene products in the formation of xanthan from its pentasaccharide repeating unit by Xanthomonas campestris
}

\author{
Adrián A. Vojnov, ${ }^{1} \dagger$ Angeles Zorreguieta, ${ }^{1} \dagger$ J. Maxwell Dow, ${ }^{2}$ \\ Michael J. Daniels ${ }^{2}$ and Marcelo A. Dankert ${ }^{1}$
}

1 Instituto de Investigaciones Bioquímicas Fundación Campomar, Facultad de Ciencias Exactas y Naturales and Consejo Nacional de Investigaciones Científicas y Técnicas, Av. Patricias Argentinas 435, 1405 Buenos Aires, Argentina

2 The Sainsbury Laboratory, John Innes Centre, Norwich Research Park, Colney Lane,

Norwich NR4 7UH, UK

\author{
Author for correspondence: M. A. Dankert. Tel: +54 18634012. Fax: +54 18652246. \\ e-mail: mdankert@iris.iib.uba.ar
}

Keywords: xanthan biosynthesis, Xanthomonas campestris, gumB and gum $\mathrm{C}$ genes, pentasaccharide precursor

\section{INTRODUCTION}

The bacterial plant pathogen Xanthomonas campestris produces an extracellular polysaccharide (EPS) called xanthan, which is of great industrial importance. Xanthan is a polymer comprising repeating pentasaccharide units with the structure mannose1,4- $\beta$-glucuronic acid-1,2- $\beta$-mannose-1,3- $\alpha$-cellobiose (Jansson et al., 1975). The pentasaccharide units are derivatized with acetyl and pyruvyl moieties (Cadmus et al., 1976; Stankowski et al., 1993). In vitro studies have indicated that the biosynthesis of xanthan gum occurs in at least two stages (Ielpi et al., 1993). In the first, the repeating unit is sequentially assembled linked to a polyprenol through a diphosphate bridge. In the second

†Present Address: John Innes Centre, Norwich Research Park, Colney Lane, Norwich NR4 7UH, UK.

Abbreviation: EPS, extracellular polysaccharide. stage, the repeating units are polymerized and the polymer liberated into the growth medium.

The genes that encode the enzymes involved in the transfer of the sugars and of the non-glycosidic substituents are located in a cluster (Barrere et al., 1986; Harding et al., 1987; Thorne et al., 1987) which comprises 12 predicted ORFs, gumB-gumM (Capage et al., 1987; Vanderslice et al., 1990). Transcriptional analysis has shown that the gum genes are mainly expressed as an operon from a promoter upstream of the first gene, gumB (Katzen et al., 1996). Secondary (weak) promoters may exist upstream of gumK (Katzen et al., 1996) and gumD (Vanderslice et al., 1990; Pollock et al., 1994). The function of some of the gene products has been established. GumD, GumH, GumI, GumK and GumM are known to be involved in the assembly of the pentasaccharide lipid intermediate. GumL is the pyruvate ketal transferase (Marzocca et al., 1991). GumB, GumC, GumE and Gum J are speculated to have a role in the polymerization and translocation of xanthan (Van- 
derslice et al., 1990; Paulsen et al., 1997). Direct evidence for the role of these latter gene products is lacking, perhaps in part due to the apparent lethal effects of transposon insertions in some of these genes (Capage et al., 1987; Vanderslice et al., 1990; Katzen et al., 1996).

Xanthan-deficient mutants of $X$. campestris pv. campestris have been derived from the wild-type strain 8004 by Tn 5 mutagenesis (Barrère et al., 1986). In this paper we report further genetic and biochemical analyses of one of these mutants, strain 8397, which provide evidence for a role for $g u m B$ and $g u m C$ in the formation of high-molecular-mass xanthan from its pentasaccharide repeating unit.

\section{METHODS}

Strains and microbiological techniques. The $X$. campestris wild-type strain 8004 (Turner et al., 1984) and xanthandeficient mutant 8397 (Barrère et al., 1986) were grown in PYM medium as reported by Cadmus et al. (1976). The Escherichia coli strain used in transformation was DH5 $\alpha$ (Sambrook et al., 1989) and was grown at $37^{\circ} \mathrm{C}$ in LuriaBertani (LB) medium (Maniatis et al., 1982). Mating procedures were as described by Turner et al. $(1984,1985)$. When necessary, appropriate antibiotics were added: kanamycin $\left(50 \mu \mathrm{g} \mathrm{ml}^{-1}\right)$, rifampicin $\left(50 \mu \mathrm{g} \mathrm{ml}^{-1}\right)$ and tetracycline (5 and $10 \mu \mathrm{g} \mathrm{ml}^{-1}$ to $X$. campestris and E. coli cultures, respectively). To detect DNA inserts cloned for $\beta$-galactosidase interruption of $\alpha$-complementation on plates, X-Gal and IPTG were added to solid medium.

DNA manipulations. Preparation of plasmid DNA from $E$. coli, agarose gel electrophoresis, cloning procedures and Southern hybridization were carried out following established protocols (Maniatis et al., 1982). Total DNA from $X$. campestris was isolated according to Hull et al. (1981) and X. campestris plasmid DNA was isolated as reported by Harding et al. (1987).

Subclones of the gum gene cluster. Subclones of the gum gene cluster carrying gumb alone or gumB and gum $C$ together were obtained by PCR using as template pIZD15-261 which carries the entire gum cluster cloned in cosmid pRK311 (Katzen et al., 1996). The primers used to amplify gumB alone were P1 $\left(5^{\prime}\right.$ CCCCAAGCTTCCAACGCCGTCAAAAA $\left.3^{\prime}\right)$ and P2 (5' GAAGATCTGCGACGAAGAGGAACGA 3'). To amplify the gumBC genes the primers were P1 and P3 $\left(5^{\prime}\right.$ GAAGATCTGCGGTATCGACGATGGT 3'). Primer sequences were derived from the sequence of the gum gene cluster determined by Capage et al. (1987). The conditions of PCR (30 cycles) were: $1 \mathrm{~min}$ at $94^{\circ} \mathrm{C}, 2 \mathrm{~min}$ at $55^{\circ} \mathrm{C}$ and $1 \mathrm{~min}$ at $72^{\circ} \mathrm{C}$, followed by $15 \mathrm{~min}$ at $72^{\circ} \mathrm{C}$. The PCR fragments were cloned into pGEM-T (Promega). The insert DNA was excised by digestion with HindIII and BglII and ligated into pRK404 (Ditta et al., 1985) cut with HindIII and BamHI to produce pAV1 (gumB) and pAV2 (gumBC). To obtain gumC alone, a deletion was created in the $g u m B$ gene in the pGEM-T derivative carrying gumB and $g u m C$. This plasmid was cut with $\mathrm{BamHI}$ and EcoRI (which are both unique sites), the ends were filled and the plasmid religated. The insert DNA was excised by digestion with HindIII and BglII and ligated into pRK404 cut with HindIII and BamHI to produce pAV3 $(g u m C)$. The construction of this deletion derivative was checked by sequencing.

DNA sequencing to determine the site of Tn5 insertion in strain 8397. The $1.9 \mathrm{~kb}$ EcoRI fragment containing the Tn5 insert was cloned in pUC19 and sequenced with a Sequencing Kit from Pharmacia-LKB using primers based on the sequence of gumB.

Chemicals. UDP-D- $\left[{ }^{14} \mathrm{C}\right]$ glucose (UDP- $\left[{ }^{14} \mathrm{C}\right] \mathrm{Glc}, 300 \mathrm{Ci} \mathrm{mol}{ }^{-1}$, $11 \cdot 1 \mathrm{TBq} \mathrm{mol}^{-1}$ ), UDP-D- $\left[{ }^{14} \mathrm{C}\right]$ glucuronic acid (UDP- $\left[{ }^{14} \mathrm{C}\right]-$ GlcA, $\left.\quad 300 \mathrm{Ci} \mathrm{mol}^{-1}, \quad 11 \cdot 1 \mathrm{TBq} \mathrm{mol}^{-1}\right)$ and GDP-D- $\left[{ }^{14} \mathrm{C}\right]-$ mannose (GDP- $\left[{ }^{14} \mathrm{C}\right] \mathrm{Man}, 238.9 \mathrm{Ci} \mathrm{mol}^{-1}, 8.8 \mathrm{TBq} \mathrm{mol}^{-1}$ ) were prepared as described previously (Couso et al., 1980; García et al., 1974). UDP-glucose, GDP-mannose and UDPglucuronic acid were purchased from Sigma. Restriction enzymes and T4 DNA ligase were obtained from New England Biolabs. Enzymes were used under the conditions specified by the suppliers.

In vitro analysis of biosynthesis of lipid intermediates and xanthan. In vitro analysis of xanthan biosynthetic steps was done radiochemically using bacterial cells treated with EDTA (Ielpi et al., 1981a). Cells were grown as described by Cadmus et al. (1976) and harvested by centrifugation at lateexponential phase. The cell pellet was resuspended in $0.01 \mathrm{M}$ EDTA/Tris buffer $(\mathrm{pH} 8 \cdot 2$ ), and frozen and thawed several times before use.

Assay procedure. The standard incubation mixture contained $70 \mathrm{mM}$ Tris/HCl buffer ( $\mathrm{pH} \mathrm{8.2),} 5 \mathrm{mM} \mathrm{MgCl}_{2}$, EDTAtreated cells (about $0.6-0.8 \mathrm{mg}$ protein), and UDP- $\left[{ }^{14} \mathrm{C}\right] \mathrm{Glc}$ $(17 \mu \mathrm{M})$ or UDP- $\left[{ }^{14} \mathrm{C}\right] \mathrm{GlcA}(17 \mu \mathrm{M})$ or GDP- $\left[{ }^{14} \mathrm{C}\right] \mathrm{Man}$ $(17 \mu \mathrm{M})$, as indicated in each case. The unlabelled sugar nucleotides, UDP-Glc, UDP-GlcA and GDP-Man $(357 \mu \mathrm{M}$ each) were added where appropriate. The total reaction volume was $70 \mu \mathrm{l}$. The reactions were performed for $30 \mathrm{~min}$ at $20^{\circ} \mathrm{C}$ and were stopped by adding $0.5 \mathrm{ml} 70 \mathrm{mM}$ Tris/ $\mathrm{HCl}$ buffer (pH 8.2) containing $30 \mathrm{mM}$ EDTA. The mixtures were centrifuged in an Eppendorf centrifuge at $14000 \mathrm{~g}$ for $2 \mathrm{~min}$ and the pellets were resuspended and washed twice with Tris/HCl buffer without EDTA.

For analysis of xanthan production, the combined supernatants were hydrolysed at $\mathrm{pH} 2$ (see below) to destroy the excess of sugar nucleotide donors, and dialysed twice against $70 \mathrm{mM}$ Tris $/ \mathrm{HCl}(2 \mathrm{l})$ for $2 \mathrm{~h}$ and then overnight against distilled water. The dialysed samples were concentrated under reduced pressure before gel filtration analysis on BioGel A $5 \mathrm{~m}$ (Bio-Rad) to determine polymer formation. The column $(110 \times 1 \cdot 2 \mathrm{~cm})$ was equilibrated and eluted with $0 \cdot 1 \mathrm{M}$ pyridinium acetate buffer $(\mathrm{pH} 5.0), 0.5 \mathrm{ml}$ fractions were collected at a flow rate of $0.25 \mathrm{ml} \mathrm{min}$ mo $^{-1}$ and $0.1 \mathrm{ml}$ aliquots were taken for counting of radioactivity. Material in the exclusion volume for high-molecular-mass materials has been previously characterized and shown to be xanthan (Ielpi et al., 1993).

For analysis of lipid intermediates, the washed cell pellets were extracted three times with $0.2 \mathrm{ml}$ chloroform/methanol/water $(1: 2: 0 \cdot 3$, by vol.) This extract, which contains the polyprenollinked $\left[{ }^{14} \mathrm{C}\right]$ oligosaccharides (Ielpi et al., 1981) will be referred to as the organic solvent extract.

Chemical treatments. Mild acid hydrolysis was carried out at $\mathrm{pH} 2\left(0.01 \mathrm{M} \mathrm{HCl}\right.$ ) and $100^{\circ} \mathrm{C}$ for $10 \mathrm{~min}$ (Couso et al., 1982). Cyclic phosphoric esters and diphosphoric esters were cleaved by treatment at $\mathrm{pH}(0.1 \mathrm{M} \mathrm{HCl})$ and $100^{\circ} \mathrm{C}$ for $10 \mathrm{~min}$. Total hydrolysis was performed with $1 \mathrm{M} \mathrm{HCl}$ at $100^{\circ} \mathrm{C}$ for $16 \mathrm{~h}$ in sealed tubes.

Chromatography and electrophoresis. Paper chromatography and electrophoresis techniques, as well as the location procedures for the different compounds, were as decribed previously (Couso et al., 1980; García et al., 1974). The following solvents were used: solvent A, pyridine/acetic 
acid/water (1:0.04:9, by vol.), $\mathrm{pH} 6.5$; solvent $\mathrm{B}$, 2propanol/acetic acid/water (27:4:9, by vol.); solvent $\mathrm{C}$, $0 \cdot 1 \mathrm{M}$ sodium molybdate, $\mathrm{pH} 5 \cdot 0$. Radioactivity was detected with a Packard radiochromatogram scanner, model 7201 (Packard).

DEAE-cellulose column chromatography was on a column $(1 \times 60 \mathrm{~cm})$ equilibrated with methanol/water $(99: 1, \mathrm{v} / \mathrm{v})$ and was eluted with a linear gradient of ammonium acetate $(0-2 \mathrm{M})$ in the same solvent in a total volume of $400 \mathrm{ml}$, as reported previously (García et al., 1974). The radioactivity in $0.25 \mathrm{ml}$ aliquots of each fraction $(3 \mathrm{ml})$ were counted as described by Bray (1960) with a 1214 Rackbeta Wallac liquid scintillation counter.

Estimation of xanthan production in liquid cultures. To estimate xanthan production, strains were cultured at $28^{\circ} \mathrm{C}$ in $50 \mathrm{ml}$ PYM liquid medium supplemented with $2 \%(\mathrm{w} / \mathrm{v})$ glucose in $250 \mathrm{ml}$ flasks, using an orbital shaker rotating at 200 r.p.m. The cells were removed by centrifugation $(25000 \mathrm{~g}$ for $30 \mathrm{~min}$ ), the supernatant fluids were supplemented with $\mathrm{KCl}$ at $1 \%(\mathrm{w} / \mathrm{v})$ final concentration and 2 vols ethanol were added. The precipitated crude xanthan was collected, dried and weighed. The cells were washed by centrifugation in distilled water. The weight of cells after removal of all excess water was taken as wet weight. Duplicate measurements of xanthan production and wet weight were made.

\section{RESULTS}

\section{Location of the Tn5 insertion in the xanthan-deficient mutant strain 8397}

The xanthan-deficient $X$. campestris strain 8397 is a derivative of wild-type strain 8004 which carries a Tn5 insertion in the gum cluster of genes, specifically within a $1.9 \mathrm{~kb}$ EcoRI fragment (Barrère et al., 1986). Analysis of the restriction fragment pattern of the gum gene cluster suggested that the insertion was in the $1.9 \mathrm{~kb}$ EcoRI DNA fragment that carries the gumB gene. This

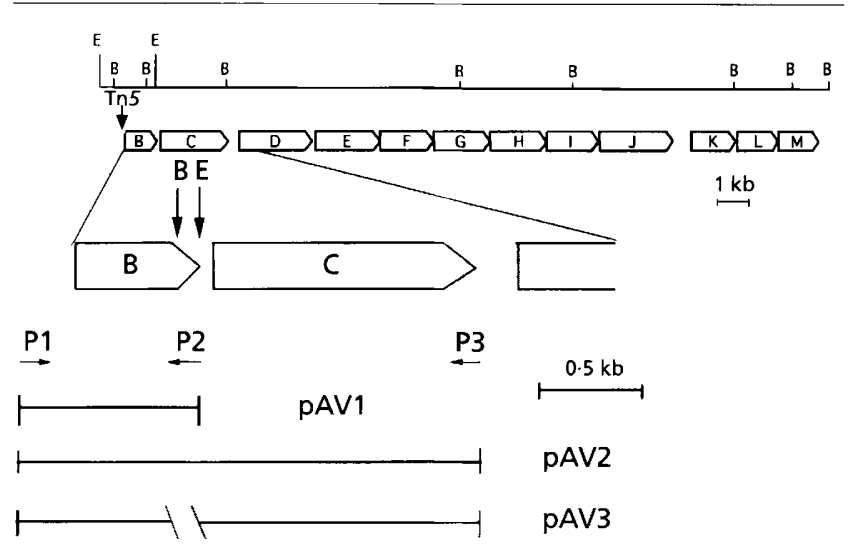

Fig. 1. Restriction map of the gum gene cluster of $X$. campestris and construction of the subclones used for complementation studies. The restriction sites for EcoRI (E) and $B a m H I(B)$ and the organization of the genes in the gum cluster are shown in the upper part of the figure. The lower part shows the annealing positions of the primers $\mathrm{P} 1, \mathrm{P} 2$ and $\mathrm{P} 3$ used to generate the subclones pAV1 and PAV2 by PCR and the position of the EcoRI (E) and $B a m H I(B)$ sites used to create the deletion derivative pAV3. location was confirmed by Southern blotting (data not shown). To determine the exact site of insertion, the $7.7 \mathrm{~kb}$ EcoRI fragment from the mutant 8397 , comprising the original $1.9 \mathrm{~kb}$ fragment and the $\operatorname{Tn} 5$ transposon $(5.8 \mathrm{~kb})$, was isolated, cloned into pUC19 and subjected to sequencing using primers based on the sequence of $g u m B$. This sequence analysis located the Tn5 insertion $15 \mathrm{bp}$ upstream of the translation initiation site of the gumB gene (Fig. 1). Although an insertion at this location might be expected to have polar effects on the expression of all of the genes of the gum operon (Katzen et al., 1996), subsequent examination of the various steps in xanthan biosynthesis by in vitro radiochemical methods suggested that this was not the case.

\section{Radiochemical analysis of xanthan biosynthetic steps in the wild-type strain 8004 and mutant strain 8397}

EDTA-treated cells of the wild-type strain 8004 showed substantial incorporation of radioactivity from UDP$\left[{ }^{14} \mathrm{C}\right] \mathrm{Glc}$, UDP- $\left[{ }^{14} \mathrm{C}\right] \mathrm{GlcA}$ or GDP- $\left[{ }^{14} \mathrm{C}\right] \mathrm{Man}$ into both the organic solvent extract (lipid-linked intermediates) and polymer fractions (Table 1). In contrast to strain 8004 , the mutant did not incorporate any radioactivity into the polymeric fraction, although levels of incorporation into the organic solvent fraction were comparable to those obtained with the wild-type strain (Table 1).

The radiolabelled materials in the organic solvent extract of strain 8397 labelled from UDP- $\left[{ }^{14} \mathrm{C}\right] \mathrm{Glc}$ were subjected to paper electrophoresis in solvent $\mathrm{A}$ both before and after mild acid hydrolysis $(\mathrm{pH} \mathrm{2,10} \mathrm{min,}$ $\left.100{ }^{\circ} \mathrm{C}\right)$. Although the unhydrolysed material remained at the origin of the electrophoretogram (Fig. 2a i), after mild acid hydrolysis five labelled components were resolved (Fig. $2 \mathrm{~b}$ i). The major component behaved as a neutral compound on paper electrophoresis. On paper chromatography in solvent $\mathrm{B}$, this material had the mobility of monomeric glucose. The two fastest moving components on paper electrophoresis had the mobilities of glucose phosphate and glucose cyclical phosphate. All three of these components are likely to have been released by mild acid hydrolysis from a lipid-diphosphate glucose (Ielpi et al., 1981a, b, 1983). The component with mobility relative to UMP $\left(R_{\mathrm{UMP}}\right)$ of 0.6 was subjected to paper chromatography in solvent B (Fig. 2c i). Two components with the expected mobilities of the pentasaccharide repeating unit and its acetylated derivative (Ielpi et al., 1981a, 1983) were resolved. The compound with $R_{\mathrm{UMP}}$ of 1 was treated at $\mathrm{pH} 2$ for $90 \mathrm{~min}$ at $100^{\circ} \mathrm{C}$ and then submitted to electrophoresis in solvent $A$. The major product behaved as the pentasaccharide $\left(R_{\mathrm{UMP}}\right.$ of $\left.0 \cdot 6\right)$. All these properties of the component with $R_{\mathrm{UMP}}$ of 1 are consistent with it being the pyruvylated pentasaccharide derivative which has been characterized previously (Ielpi et al., 1981b).

The analysis of radiolabelled components derived from UDP- $\left[{ }^{14} \mathrm{C}\right] \mathrm{GlcA}$ and GDP- $\left[{ }^{14} \mathrm{C}\right]$ Man provided further support for the notion that strain 8397 can synthesize a 
Table 1. Incorporation of radioactive sugars into lipid-linked sugars and polysaccharides by strains of $X$. campestris

EDTA-treated cells of wild-type strain 8004 and mutant strain 8397 were incubated with labelled nucleotide sugar donors and incorporation of radiolabel into the organic solvent phase (representing potential lipid-linked intermediates) and into the polymeric fraction (EPS) was measured as described in Methods. Incorporation of label is expressed as c.p.m. (mg protein) ${ }^{-1}$ and also in parentheses as pmol sugar $(\mathrm{mg} \text { protein })^{-1}$. Values given are the means of three determinations which differed from the mean by $<10 \%$.

\begin{tabular}{|llllll|}
\hline \multirow{2}{*}{$\begin{array}{l}\text { Radioactive } \\
\text { precursor }\end{array}$} & \multicolumn{2}{c}{ Strain 8004 } & & \multicolumn{2}{c|}{ Strain 8397 } \\
\cline { 2 - 3 } \cline { 5 - 6 } & Organic phase & EPS & & Organic phase & EPS \\
\hline UDP-[ $\left[{ }^{14} \mathrm{C}\right] \mathrm{Glc}$ & $52000(84)$ & $43400(70)$ & & $38053(62)$ & $<100(<0 \cdot 2)$ \\
GDP-[ $\left[{ }^{4} \mathrm{C}\right] \mathrm{Man}$ & $62000(125)$ & $48000(97)$ & & $39200(79)$ & $<100(<0 \cdot 2)$ \\
UDP-[ $\left[{ }^{14} \mathrm{C}\right] \mathrm{Glc} A$ & $54000(87)$ & $28200(46)$ & & $42173(68)$ & $<100(<0 \cdot 2)$ \\
\hline
\end{tabular}

(i)

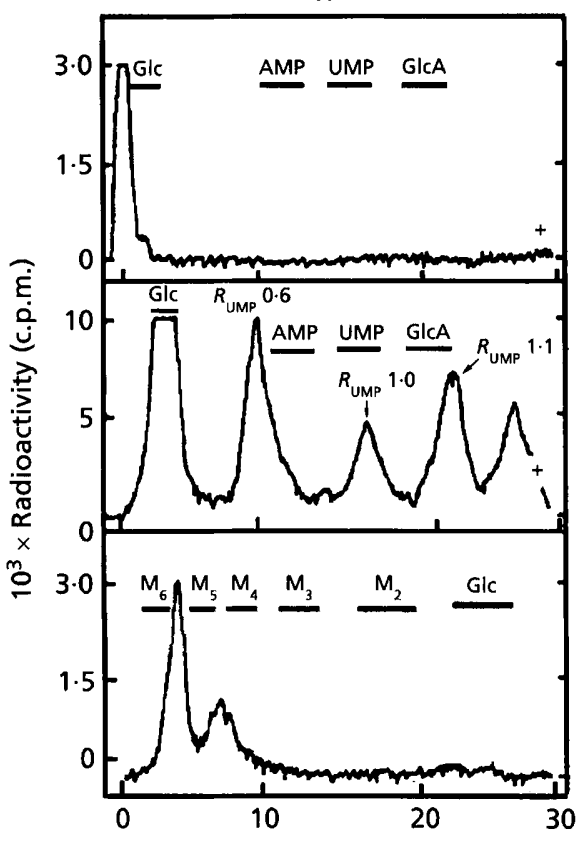

(ii)

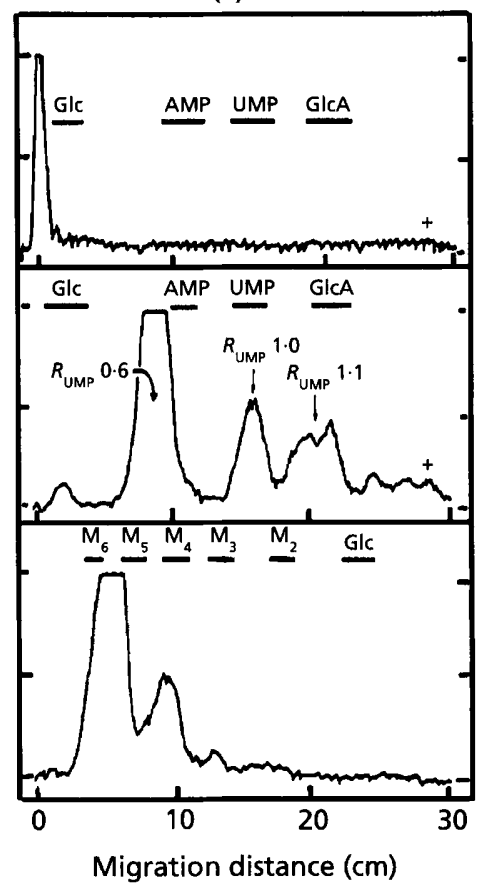

(iii)

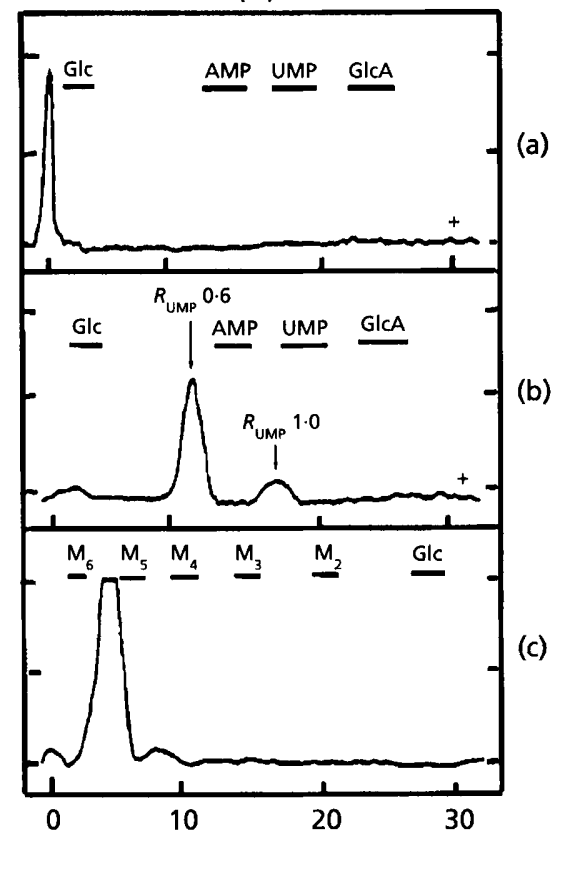

Fig. 2. Radiochemical analysis of lipid-linked intermediates of xanthan biosynthesis in $X$. campestris strain 8397 using UDP- $\left[{ }^{14} \mathrm{C}\right]$ glucose (i), UDP- $\left[{ }^{14} \mathrm{C}\right]$ glucuronic acid (ii) or GDP- $\left[{ }^{14} \mathrm{C}\right]$ mannose (iii) as labelled sugar donor. EDTA-treated cells were incubated with the labelled sugar donor and unlabelled GDP-mannose and UDP-glucuronic acid (i), UDP-glucose and GDP-mannose (ii) or UDP-glucose and UDP-glucuronic acid (iii). Labelled material incorporated into chloroform/methanol/water (1:2:0.3, by vol.) was analysed by paper electrophoresis in solvent $A$ both before (a) and after (b) mild acid hydrolysis. The material with $R_{\mathrm{UMP}}$ of 0.6 released by mild acid hydrolysis was further analysed by paper chromatography in solvent B (c). The positions of markers for adenosine monophosphate (AMP), uridine monophosphate (UMP), glucose (Glc), glucuronic acid (GlCA) and malto-oligosaccharides of degree of polymerization 2-6 $\left(M_{2}-M_{6}\right)$ are indicated.

pentasaccharide-lipid intermediate. $\left[{ }^{14} \mathrm{C}\right] \mathrm{GlcA}$-labelled materials in the organic solvent phase remained at the origin on paper electrophoresis in solvent A (Fig. 2a ii) but after mild acid hydrolysis most of the material migrated as a pentasaccharide repeating unit $\left(R_{\mathrm{UMP}}\right.$ of $0 \cdot 6)$ (Fig. $2 \mathrm{~b}$ ii). This material analysed by paper chromatography in solvent B indicated the presence of the pentasaccharide and its acetylated derivatives (Fig. $2 c$ ii). The pyruvylated pentasaccharide derivative $\left(R_{\text {UMP }}\right.$ of 1$)$ was also detected (Fig. 2b ii). A third compound with the mobility of glucuronic acid was also obtained. This compound had the same behaviour as galacturonic acid but not glucuronic acid on paper electrophoresis in solvent $\mathrm{C}$. This galacturonic acid was 


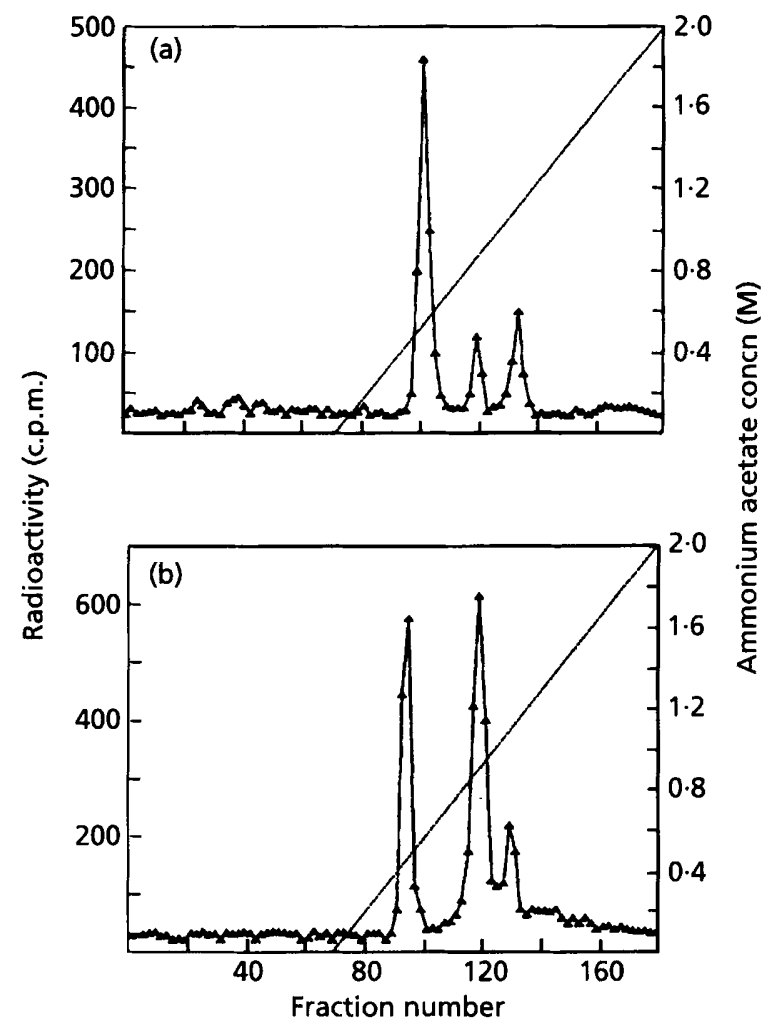

Fig. 3. Ion-exchange chromatography on DEAE-cellulose of lipid-linked intermediates in mutant strain 8397 (a) and wildtype strain 8004 (b). EDTA-treated cells were incubated with UDP- $\left[{ }^{14} \mathrm{C}\right]$ glucose and unlabelled UDP-glucuronic acid and GDPmannose as described in the legend to Fig. 2. The column was eluted with a gradient of ammonium acetate in methanol/water $(99: 1, \mathrm{v} / \mathrm{v})$.

probably liberated from a lipid-bound galacturonide as has already been described (Baldessari et al., 1990). Organic-solvent-phase materials labelled with ${ }^{14} \mathrm{C}$-man- nose from GDP- $\left[{ }^{14} \mathrm{C}\right]$ Man also remained at the origin on paper electrophoresis in solvent A (Fig. 2a iii). However, after mild acid hydrolysis, labelled components with the mobility on paper electrophoresis of the pentasaccharide and pyruvylated pentasaccharide were obtained (Fig. 2b iii). On paper chromatography in solvent $\mathrm{B}$, the major component appeared to be the pentasaccharide (Fig. 2c iii).

The ${ }^{14} \mathrm{C}$-glucose-labelled components in the organic solvent phase were also analysed by DEAE chromatography. Three compounds eluting at $0.5,0.8-0.9$ and 1.1 M ammonium acetate were observed (Fig. 3a). These components were separately hydrolysed with mild acid and were analysed by paper electrophoresis and paper chromatography as described above. This analysis showed that the compounds eluting at $0.5,0.8-0.9$ and $1 \cdot 1 \mathrm{M}$ ammonium acetate were lipid diphosphate glucose, lipid diphosphate pentasaccharide and lipid pyruvylated pentasaccharide, respectively (data not shown). These three components were also seen in chromatograms of ${ }^{14} \mathrm{C}$-glucose-labelled components of the wildtype (Fig. 3b), although the components were present in different proportions.

\section{Restoration of xanthan biosynthesis by subclones of the gum gene cluster}

The biochemical analysis of strain 8397 indicated that although the mutant was capable of synthesis of the pentasaccharide lipid intermediate it could not synthesize xanthan. Synthesis of the pentasaccharide-lipid intermediate requires the action of genes downstream of gumB and gumC, which suggests that the effects of the $\operatorname{Tn} 5$ insertion $15 \mathrm{bp}$ upstream of the translation initiation site of $g u m B$ are not polar. We reasoned that this was likely to be due to the action of secondary promoters internal to the gum gene cluster, in particular that suggested to lie upstream of $g u m D$, which however was not detected by other workers (Katzen et al., 1996).

Table 2. Production of EPS by strains of $X$. campestris

The in vivo production of EPS by different strains was determined gravimetrically after ethanol precipitation from the culture supernatant and is expressed both in terms of the volume of culture and of the wet weight of cells. Production of EPS was also measured in vitro by following the incorporation of $\left[{ }^{14} \mathrm{C}\right] \mathrm{GlcA}$ from UDP- $\left[{ }^{14} \mathrm{C}\right] \mathrm{GlcA}$ by EDTA-treated cells. Values given are the means of two determinations which differed from the mean by $<5 \%$. The experiment was repeated twice with essentially the same results. NA, Not available.

\begin{tabular}{|c|c|c|c|c|}
\hline \multirow[t]{2}{*}{ Strain } & \multirow{2}{*}{$\begin{array}{c}\text { Relevant } \\
\text { genes carried } \\
\text { on plasmid }\end{array}$} & \multicolumn{2}{|c|}{ EPS production in vivo } & \multirow{2}{*}{ 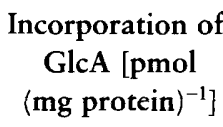 } \\
\hline & & $\mathrm{g}(1 \text { culture })^{-1}$ & $\mathrm{mg}(\mathrm{g} \text { wet wt cells) })^{-1}$ & \\
\hline 8004 & & $6 \cdot 46$ & $420 \cdot 0$ & $42 \cdot 0$ \\
\hline 8397 & & 0.08 & $4 \cdot 8$ & $<0 \cdot 2$ \\
\hline $8397 / \mathrm{pAV} 1$ & $\operatorname{gumB}$ & $0 \cdot 10$ & $6 \cdot 6$ & $<0 \cdot 2$ \\
\hline $8397 / \mathrm{pAV} 2$ & $\operatorname{gum} B, \operatorname{gum} C$ & $1 \cdot 76$ & $119 \cdot 0$ & $14 \cdot 8$ \\
\hline $8397 / \mathrm{pAV} 3$ & gum C & 0.03 & $4 \cdot 2$ & NA \\
\hline $8397 / \mathrm{pIZD} 15-261$ & $\operatorname{gumB} B-M$ & $7 \cdot 40$ & $480 \cdot 0$ & $47 \cdot 5$ \\
\hline
\end{tabular}


These phenotypes of the mutant suggested that we could use strain 8397 as a tool to test the proposed roles of the gumB and gum $C$ gene products in the later steps of xanthan biosynthesis by providing these genes in trans either together or separately. Synthesis of xanthan was estimated both by precipitation of the polymer from cultures and radiometrically by following the incorporation of label from UDP- $\left[{ }^{14} \mathrm{C}\right] \mathrm{GlcA}$ into highmolecular-mass material by EDTA-treated cells. As an initial control, the recombinant plasmid pIZD15-261, which carries the whole gum gene cluster (Katzen et al., 1996), was introduced into the mutant. The synthesis of xanthan as estimated by both methods was restored; the levels of xanthan were slightly higher than in the wildtype (Table 2). Although provision of $g u m B$ or gumC genes separately (as the recombinant plasmids pAV1 and $\mathrm{pAV} 3$ ) had no effect on xanthan production, provision of the two genes together on the plasmid pAV2 allowed restoration of xanthan production to levels approximately $28 \%$ of the wild-type (Table 2 ). The inability of gumB alone to complement strain 8397 for xanthan production was not due to errors induced by PCR amplification; sequencing of the amplified DNA showed that it would encode an unaltered GumB protein. These results clearly suggest that GumB and GumC operate together to synthesize xanthan from the pentasaccharide subunit.

\section{DISCUSSION}

The mutant strain 8397 , which carries a $\operatorname{Tn} 5$ insertion immediately upstream of $\mathrm{gumB}$, is unable to synthesize xanthan although it can still synthesize the lipid-linked pentasaccharide repeating unit of xanthan. Provision of gumB and gumC together restores xanthan synthesis to strain 8397 to approximately $28 \%$ of wild-type levels. The simplest interpretation of these results is that $\operatorname{Tn} 5$ insertion has a polar effect on the expression of gumB and $g u m C$ but that expression of the rest of the gum cluster (which is required for the synthesis of the pentasaccharide) is directed from a promoter upstream of gumD. The incomplete restoration of xanthan production by complementation with gumB and gumC together may be a result of lower in vivo levels of the pentasaccharide-lipid intermediate in strain 8397 compared to the wild-type. This is suggested by the lower incorporation of radiolabelled sugars into this fraction by EDTA-treated cells of strain 8397 compared to the wild-type.

Polymerization and export of bacterial extracellular polysaccharides are in general poorly understood processes. Although our data implicate GumB and GumC in the processing of the lipid-linked pentasaccharide into mature extracellular xanthan, we cannot define precisely which steps these two proteins mediate. These processing steps may include 'flipping' of the lipid-pentasaccharide intermediate across the cytoplasmic membrane, pore formation, transport through one or both membranes and the polymerization step which incorporates the pentasaccharide into the growing xanthan chain. A similar situation exists in studies of the biosynthesis of succinoglycan in Rhizobium (now Sinorbizobium) meliloti which appears to have many parallels with the biosynthesis of xanthan in $X$. campestris (Reuber \& Walker, 1991; Glucksmann et al., $1993 a, b)$. Nineteen exo genes are required for the synthesis of succinoglycan, which is a polymer of octasaccharide units comprising one galactose and seven glucose residues with acetyl, pyruvyl and succinyl modifications. A combination of genetic and biochemical analysis has established precise roles for 15 of the exo genes in the biosynthesis of the octasaccharide-lipid intermediate, which is believed to be assembled in the cytoplasm. However precise roles for products of the exoP, exo $Q$ and exoT genes, which are required to process the octasaccharide subunits into the mature polysaccharide, are yet to be established, although all three genes encode membrane-spanning proteins (Müller et al., 1993; Glucksmann et al., 1993b).

On the basis of computer analysis, Paulsen et al. (1997) suggested that GumB and GumC are involved in translocation of xanthan across the cytoplasmic and outer membranes. GumB was suggested to be an outermembrane protein belonging to a small family which includes ExoF of $S$. meliloti and $\mathrm{KpsD}$, a protein known to be involved in translocation of the capsular polysaccharide of E. coli. GumC was suggested to be localized in the cytoplasmic membrane and to have both cytoplasmic and periplasmic domains. The cytoplasmic domain bears an ATP-binding motif. It is tempting to speculate from our own data and the work of Paulsen $e t$ al. (1997) that the polymerization of xanthan is tightly coupled to its translocation across the two membranes such that, in the absence of translocation, synthesis is halted.

\section{ACKNOWLEDGEMENTS}

We acknowledge the skilful technical assistance of Susano Raffo and María de los Angeles Curto in the preparation of radiolabelled sugar nucleotides. M.A.D. is a Career Investigator of the Consejo Nacional de Investigaciones Científicas y Técnicas (CONICET), Argentina. This work was supported in part by grants from the Swedish Agency for Research Cooperation with Developing Countries (SAREC) and from Shell CAPSA. The Sainsbury Laboratory is supported by a grant from the Gatsby Charitable Foundation. This work was carried out according to the provisions of the Ministry of Agriculture, Fisheries and Food, licence PHF1185/8(48) issued under the Plant Health (Great Britain) Order 1987 (Statutory Instrument 1758).

\section{REFERENCES}

Baldessari, A. L., lelpi, L. \& Dankert, M. A. (1990). A novel galacturonide from Xanthomonas campestris. J Gen Microbiol 136, 1501-1507.

Barrère, G. C., Barber, C. E. \& Daniels, M. J. (1986). Molecular cloning of genes involved in the production of the extracellular polysaccharide xanthan by Xanthomonas campestris pv. campestris. Int J Biol Macromol 8, 372-374. 
Bray, G. A. (1960). A simple efficient liquid scintillator for counting aqueous solutions in a liquid scintillation counter. Anal Biochem 1, 279-285.

Cadmus, M. C., Rojovin, S. P., Burton, K. A., Pittsley, J. E., Knutson, C. A. \& Jeanes, A. (1976). Colonial variation in Xanthomonas campestris NRRL B-1459 and characterization of the polysaccharide of a variant strain. Can J Microbiol 22, 942-948.

Capage, M. A., Doherty, D. H., Betlach, M. R. \& Vanderslice, R. W. (1987). Recombinant-DNA mediated production of xanthan gum. International patent WO87/05938.

Couso, R. O., lelpi, L., García, R. C. \& Dankert, M. A. (1980). Synthesis of mannosyl cellobiose diphosphate prenol in Acetobacter xylinum. Arch Biochem Biophys 204, 434-443.

Couso, R. O., lelpi, L., García, R. C. \& Dankert, M. A. (1982). Biosynthesis of polysaccharides in Acetobacter xylinum. Sequential synthesis of a heptasaccharide diphosphate prenol. Eur J Biochem 123, 617-627.

Ditta, G., Schmidhauser, T., Yakobson, E., Lu, P., Liang, X.-W., Finlay, D. R., Guiney, D. \& Helinski, R. (1985). Plasmid related to the broad host range vector pRK290, useful for gene cloning and monitoring gene expression. Plasmid 13, 149-153.

García, R. C., Recondo, E. \& Dankert, M. A. (1974). Polysaccharide biosynthesis in Acetobacter xylinum. Enzymatic synthesis of lipid diphosphate and monophosphate sugars. Eur $J$ Biochem 43, 93-105.

Glucksmann, M. A., Reuber, T. L. \& Walker, G. C. (1993a). Family of glycosyl transferases needed for the synthesis of succinoglycan by Rhizobium meliloti. J Bacteriol 175, 7033-7044.

Glucksmann, M. A., Reuber, T. L. \& Walker, G. C. (1993b). Genes needed for the modification, polymerization, export, and processing of succinoglycan by Rhizobium meliloti: a model for succinoglycan biosynthesis. J Bacteriol 175, 7045-7055.

Harding, N. E., Cleary, J. M., Cabañas, D. K., Rosen, I. G. \& Kang, K. S. (1987). Genetic and physical analysis of genes essential for xanthan gum biosynthesis in Xanthomonas campestris. J Bacteriol 169, 2854-2861.

Hull, R. A., Gill, R. E., Hsu, P., Minshew, B. H. \& Falcow, S. (1981). Construction and expression of recombinant plasmids encoding type 1 or D-mannose-resistant pili from a urinary tract infection Escherichia coli isolate. Infect Immun 33, 933-938.

lelpi, L., Couso, R. O. \& Dankert, M. A. (1981a). Lipid-linked intermediates in the biosynthesis of xanthan gum. FEBS Lett 130, 253-256.

lelpi, L., Couso, R. O. \& Dankert, M. A. (1981b). Pyruvic acid acetal residues are transferred from phosphoenolpyruvate to the pentasaccharide-P-P-lipid. Biochem Biophys Res Commun 102, 1400-1408.

lelpi, L., Couso, R. O. \& Dankert, M. A. (1983). Xanthan gum biosynthesis: acetylation occurs at the prenyl-phospho sugar stage. Biochem Int 6, 323-333.

lelpi, L., Couso, R. O. \& Dankert, M. A. (1993). Sequential assembly and polymerization of the prenol-linked pentasaccharide repeating unit of the xanthan polysaccharide in Xanthomonas campestris. J Bacteriol 175, 2490-2500.
Jansson, P. E., Kenne, L. \& Lindberg, B. (1975). Structure of the extracellular polysaccharide from Xanthomonas campestris. Carbohydr Res 45, 274-282.

Katzen, F., Becker, A., Zorreguieta A., Puhler, A. \& lelpi, L. (1996). Promotor analysis of the Xanthomonas campestris pv. campestris gum operon directing biosynthesis of the xanthan polysaccharide. J Bacteriol 178, 4313-4318.

Maniatis, T., Fritsch, E. F. \& Sambrook, J. (1982). Molecular Cloning: a Laboratory Manual. Cold Spring Harbor, NY : Cold Spring Harbor Laboratory.

Marzocca, M. P., Harding, N. E., Petroni, E. A., Cleary, J. M. \& lelpi, L. (1991). Location and cloning of the ketal pyruvate transferase gene of Xanthomonas campestris. J Bacteriol 173, 7519-7524.

Müller, P., Weng, M. W. M., Quandt, J., Arnold, W. \& Pühler, A. (1993). Genetic analysis of Rhizobium meliloti exoYFQ operon: ExoY is homologous to sugar transferases and ExoQ represents a transmembrane protein. Mol Plant-Microbe Int 6, 55-65.

Paulsen, I. T., Beness, A. M. \& Saier, M. H., Jr (1997). Computerbased analyses of the protein constituents of transport systems catalysing export of complex carbohydrates in bacteria. Microbiology 143, 2685-2699.

Pollock, T. J., Thorne, L., Yamazaki, M., Mikolajczak, M. \& Armentrout, R. W. (1994). Mechanisms of bacitracin resistance in Gram-negative bacteria that synthesise exopolysaccharides. $J$ Bacteriol 176, 6229-6237.

Reuber, T. L. \& Walker, G. C. (1991). Biosynthesis of succinoglycan, a symbiotically important exopolysaccharide of Rhizobium meliloti. Cell 74, 269-280.

Sambrook, J., Fritsch, E. F. \& Maniatis, T. (1989). Molecular Cloning: a Laboratory Manual, 2nd edn. Cold Spring Harbor, NY: Cold Spring Harbor Laboratory.

Stankowski, J. D., Mueller, B. E. \& Zeller, S. G. (1993). Location of a second $\mathrm{O}$-acetyl group in xanthan gum by the reductivecleavage method. Carbohydr Res 241, 321-326.

Thorne, L., Tansey, L. \& Pollock, T. J. (1987). Clustering of mutations blocking synthesis of xanthan gum by Xanthomonas campestris. J Bacteriol 169, 3593-3600.

Turner, P., Barber, C. \& Daniels, M. J. (1984). Behavior of the transposons $\operatorname{Tn} 5$ and $\operatorname{Tn} 7$ in Xanthomonas campestris pv. campestris. Mol Gen Genet 195, 101-107.

Turner, P., Barber, C. \& Daniels, M. J. (1985). Evidence for clustered pathogenicity genes in Xanthomonas campestris pv. campestris. Mol Gen Genet 199, 338-343.

Vanderslice, R. W., Doherty, D. H., Capage, M. A., Betlach, M. R., Hassler, R. A., Henderson, N. M., Ryan-Graniero, J. \& Tecklenburg, M. (1990). Genetic engineering of polysaccharide structure in Xanthomonas campestris. In Biomedical and Biotechnological Advances in Industrial Polysaccharides, pp. 145-156. Edited by V. Crescenzi, I. C. M. Dea, S. Paoletti, S. S. Stivala \& I. W. Sutherland. New York: Gordon \& Breach.

Received 27 November 1997; revised 23 February 1998; accepted 2 March 1998 